\title{
Analysis of Climate Variability and Trends in Southern Ethiopia
}

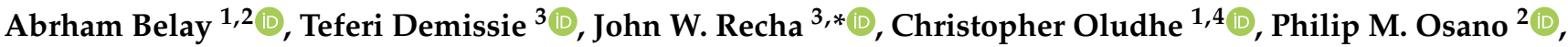 \\ Lydia A. Olaka $^{1,5}$ (iD), Dawit Solomon ${ }^{3}$ and Zerihun Berhane ${ }^{6}$ (D)
}

1 Institute for Climate Change and Adaptation, University of Nairobi, Nairobi P.O. Box 30197-00100, Kenya; abrhambelay@hu.edu.et (A.B.); coludhe@uonbi.ac.ke (C.O.); lydiaolaka@uonbi.ac.ke (L.A.O.)

2 Stockholm Environment Institute-Africa, World Agroforestry Centre, Nairobi P.O. Box 30677, Kenya; philip.osano@sei.org

3 CGIAR Research Program on Climate Change, Agriculture, and Food Security (CCAFS), International Livestock Research Institute (ILRI), Nairobi P.O. Box 30709-00100, Kenya; t.demissie@cgiar.org (T.D.); d.Solomon@cgiar.org (D.S.)

4 Department of Meteorology, University of Nairobi, Nairobi P.O Box 30197-00100, Kenya

5 Department of Geology, University of Nairobi, Nairobi P.O Box 30197-00100, Kenya

6 Center for African and Asian Studies, Addis Ababa University, Addis Ababa P.O. Box 1176, Ethiopia; zerihun.berhane@aau.edu.et

* Correspondence: j.recha@cgiar.org

Citation: Belay, A.; Demissie, T.;

Recha, J.W.; Oludhe, C.; Osano, P.M.; Olaka, L.A.; Solomon, D.; Berhane, Z. Analysis of Climate Variability and Trends in Southern Ethiopia. Climate 2021, 9, 96. https://doi.org/ 10.3390/cli9060096

Academic Editor: Forrest M. Hoffman

Received: 27 March 2021

Accepted: 28 May 2021

Published: 15 June 2021

Publisher's Note: MDPI stays neutral with regard to jurisdictional claims in published maps and institutional affiliations.

Copyright: (c) 2021 by the authors. Licensee MDPI, Basel, Switzerland. This article is an open access article distributed under the terms and conditions of the Creative Commons Attribution (CC BY) license (https:// creativecommons.org/licenses/by/ $4.0 /)$.

\begin{abstract}
This study investigated the trends and variability of seasonal and annual rainfall and temperature data over southern Ethiopia using time series analysis for the period 1983-2016. Standard Anomaly Index (SAI), Coefficient of Variation (CV), Precipitations Concentration Index (PCI), and Standard Precipitation Index (SPI) were used to examine rainfall variability and develop drought indices over southern Ethiopia. Temporal changes of rainfall trends over the study period were detected using Mann Kendall (MK) trend test and Sen's slope estimator. The results showed that the region experienced considerable rainfall variability and change that resulted in extended periods of drought and flood events within the study period. Results from SAI and SPI indicated an interannual rainfall variability with the proportions of years with below and above normal rainfall being estimated at $56 \%$ and $44 \%$ respectively. Results from the Mann Kendall trend test indicated an increasing trend of annual rainfall, Kiremt (summer) and Bega (dry) seasons whereas the Belg (spring) season rainfall showed a significant decreasing trend $(p<0.05)$. The annual rate of change for mean, maximum and minimum temperatures was found to be $0.042{ }^{\circ} \mathrm{C}, 0.027^{\circ} \mathrm{C}$, and $0.056{ }^{\circ} \mathrm{C}$ respectively. The findings from this study can be used by decision-makers in taking appropriate measures and interventions to avert the risks posed by changes in rainfall and temperature variability including extremes in order to enhance community adaptation and mitigation strategies in southern Ethiopia.
\end{abstract}

Keywords: climate change; climate variability; rainfall; temperature; mann kendall test; standard precipitation index; coefficient of variation

\section{Introduction}

Climate change is consideredone of the biggest challenges facing the world in the 21st century [1-3]. Notably, climate change and variability are as a result of either natural causes or anthropogenic (human) activities. The natural causes include changes in solar activities, orbital parameters and volcanic eruptions, while the anthropogenic causes arise from various activities that emit greenhouse gases [4]. To combat this global environmental problem, the United Nations Framework Convention on Climate Change (UNFCCC) approved the Paris agreement which is a legally binding framework to tackle global climate change. The framework focuses on low carbon development strategies with policy obligations for all the countries to keep the level of global warming to below 2 degrees Celsius [5,6].

Climate change is severely affecting many developing countries whose main economic activities largely depend on climate-sensitive sectors with low adaptative capacity [7]. 
A majority of the Sub-Saharan countries, including Ethiopia, are highly impacted upon by the adverse effects of weather and climate extremes resulting in low agricultural production and food insecurity [8]. The climate of Ethiopia has changed over the last few decades with temperatures being found to have increased by about $0.37^{\circ} \mathrm{C}$ over the last four decades [9]. A decreasing rainfall trend have also been observed in Ethiopia since the 1990s [10,11] and this decline has affected considerably the agricultural production as well as water availability in the country. The natural mode of climate variability associated with El NiñoSouthern Oscillation (ENSO) as well as increase in anthropogenic activities has greatly contributed to the observed changes inrainfall and temperature within the country $[12,13]$.

Previous studies have shown that climate variability and change have exerted a significant impact on the Ethiopian economy, particularly in the agriculture sector which is rainfall-dependent and highly dominated by traditional agricultural practices $[14,15]$. Agriculture is the backbone of the Ethiopian economy and contributes about $40 \%$ of the GDP, $80 \%$ of total employment, and $90 \%$ of exports [15]. Climate change-induced impacts have greatly affected Ethiopia's economic growth. For instance, the country experienced a 2-9\% decline in economic performance between 1991-2010 due to the impacts of climate-related extremes [16]. Climate variability and change have significantly impacted the economic growth of the country resulting in a 10\% decline of its GDP from the proposed targets and has increased income inequality by $20 \%$ [17]. Studies conducted by Gebreegziabher et al. [18] and Zewdu et al. [19] have revealed that the Ethiopian agriculture production is predicted to decline by as much as $6 \%$ to $32.5 \%$ as a consequence of climate change impacts between 2030-2050 compared with the current outputs which will make the country be dependent on food aids. [19]. A study conducted by Zewdu et al. [19] gave a detailed focus on the projected impacts of climate change on agriculture but did not provide a detailed overview of the observed climate trends and variabilities in Ethiopia. This therefore implies that further studies are needed in order to determine the observed changes in climate over the region and explore appropriate adaptation strategies.

Recent literature revealed that rainfall variability over East Africa is mainly caused by the Pacific, Indian and Atlantic oceanic interaction process such as El Niño Southern Oscillation (ENSO), Indian Ocean Dipole (IOD), other large scale atmospheric phenomena such as the Inter-Tropical Convergent Zone (ITCZ) including upper level winds such as Quasi-Biennial Oscillation (QBO) and high pressure systems in the Indian and Atlantic oceans [20-24]. Investigating the historical climate trends and future projections for Ethiopia can be a complex exercise due to the rapid changes in topography that varies from sea level to about 1290-3000 m above sea level (masl) in which the highest mountain reaches 4533 masl and consequently the climate varies from semi-desert lowlands to wettest highland areas [25]. The rainfall patterns of the country are highly variable where some areas have only one rainy season while other areas experience two or more rainy seasons [26]. Recent studies conducted in East Africa particularly in Ethiopia, on multidecadal variability of climate revealed mixed results. Various studies have shown declining trends of annual rainfall patterns in different parts of the country while other studies depicted increasing rainfall trends [13,21,25,27-29]. Rowell et al. [13] affirmed that Indian Ocean Sea Surface temperatures (SSTs) are the main cause of the East African rainfall at longer time scales.

According to Cheung et al. [30], trend analysis of annual and seasonal rainfall for over 134 stations in 13 watersheds zones in Ethiopia indicated a significant decrease in the Kiremt (June-September) rainfall for most of the watersheds located in the Southwestern and Central Rift Valley of Ethiopia. Araro et al. [31] showed that changes in the trends of temperature within highlands and lowlands were both positive and negative respectively. Asfaw et al. [28] conducted a time series analysis of rainfall amount and temperature in northern Ethiopia. The results showed an increasing trend of drought years with decreasing trends of both Belg and Kiremt rainfall patterns while changes in temperature showed an increasing trend. Shawul and Chakma [29] analyzed extreme rainfall indices and long-term rainfall variability in the upper Awash Basin which showed a high spatial and temporal 
variability of rainfall and exhibited lower rainfall concentration in the Basin. Benti and Abara [27] conducted a study in Masha district in Southern Ethiopia and reported that the annual rainfall is expected to significantly decline in the coming 35 years while the annual mean temperature will increase. The study conducted by Wagesho et al. [32] on the annual and temporal variability of rainfall over Ethiopia showed that the trend of annual and Kiremt rainfall significantly decreased in northern and western parts of Ethiopia while annual rainfall distribution showed an increasing trend in the eastern parts of the country.

Gummadi et al. [33] analyzed spatio-temporal variability of rainfall and extreme events in Ethiopia and clearly showed that Southern Ethiopia has experienced extreme rainfall events. The study suggested that a robust trend analysis would help to better understand the future projection of climate in the area. A context-specific study on climate trends and variability was also recommended. The rainy season of Ethiopia is determined mainly by ENSO and local climate indicators [33]. The central highlands and northwestern part of Ethiopia had recorded decreasing rainfall patterns during the cropping season [28]. The study used pixel-based Mann-Kendall trend analysis and Vegetation Condition Index (VCI) and the finding showed a significant countrywide drought had been recorded during El Niño 2009 and 2015 periods in the country.

In Ethiopia, El Niño creates drier conditions in various parts of the country which affected the planting season from June to September [34]. During the 2015 El Niño period, the rain was below average and farmers were forced to shift their planting season because $50-90 \%$ of annual rainfall comes from the "Kirmet and Belg" rainy season [25,35]. Ethiopia has one main rainy season that occurs from June to September and a secondary rainy season from February to May. Some regions in the south part of the country such as Borena benefit from the small rainfall during the October-December season. According to the Ethiopian National Meterological Agency (NMA), the average annual national rainfall pattern remained constant between 1951 and 2006 while Kiremt and Belg rainfall have shown highly varying patterns. Most studies conducted in Ethiopia depict inconsistences in reporting issues of climate change in Ethiopia while regional studies on climate variability and change including rainfall and temperature trends would be very useful in designing and implementing strong national adaptation plans as well as establishing an early warning system for the country. A few studies conducted in the region have revealed the effect of rainfall variability on agricultural activities such as crop damage due to erratic rainfall, floods, drought occurrence, incidences of pests and diseases $[19,25]$. Similarly, Wodaje et al. [22] indicated there was considerable spatial rainfall variability in the region. Information on rainfall anomalies, seasonal variations, and extreme rainfall and temperature trends over the study area are critically lacking. Undertaking trend analysis and variability of rainfall patterns is vital for accurate prediction of climate extremes and taking corresponding adaptation and mitigation measures [2]. In this study, the Bilatie sub-watershed in the southern region of Ethiopia was selected in order to determine the trends and variability of rainfall and temperature in the area. Even though a few studies on climate change and variability have been conducted in the region as discussed above, still there is a gap that these studies did not address as provided in the following questions: (i) have rainfall and temperature trends changed over the period 1983-2016 in the study area? (ii) how does the distribution of rainfall anomalies in the study area look like? (iii) to what extent are the variations and distribution of seasonal and annual rainfall patterns behavein the study area? Therefore, this study will sought to address these various gaps.

\section{Materials and Methods}

\subsection{Description of the Study Area}

Southern National Nationalities and Peoples Region (SNNPR) is one of the nine regional administrations of the federal republic of Ethiopia and lies between 3.451 to $9.66{ }^{\circ} \mathrm{N}$ latitude and $32.435-40.876^{\circ} \mathrm{E}$ longitude. The region has about fifty-six ethnic groups, typical cultures, languages, historic sites, and livelihood systems. The region is bordered by Kenya in the South, South Sudan in the Southwest, Gambela region in 
the north-west and surrounded by Oromia region in the North and East (See Figure 1). The total area is about $106,000 \mathrm{~km}^{2}$, which is divided into 14 administrative zones and 131 Weredas (districts) with various landscape characteristics including mountains, valleys, and gorges [36]. According to the Central Statistics Agency [37] census, the total estimated population of the region is about 15 million. The region has diverse climatic agro-ecological zones from lowland to highlands and has rich water resources of lakes and rivers.

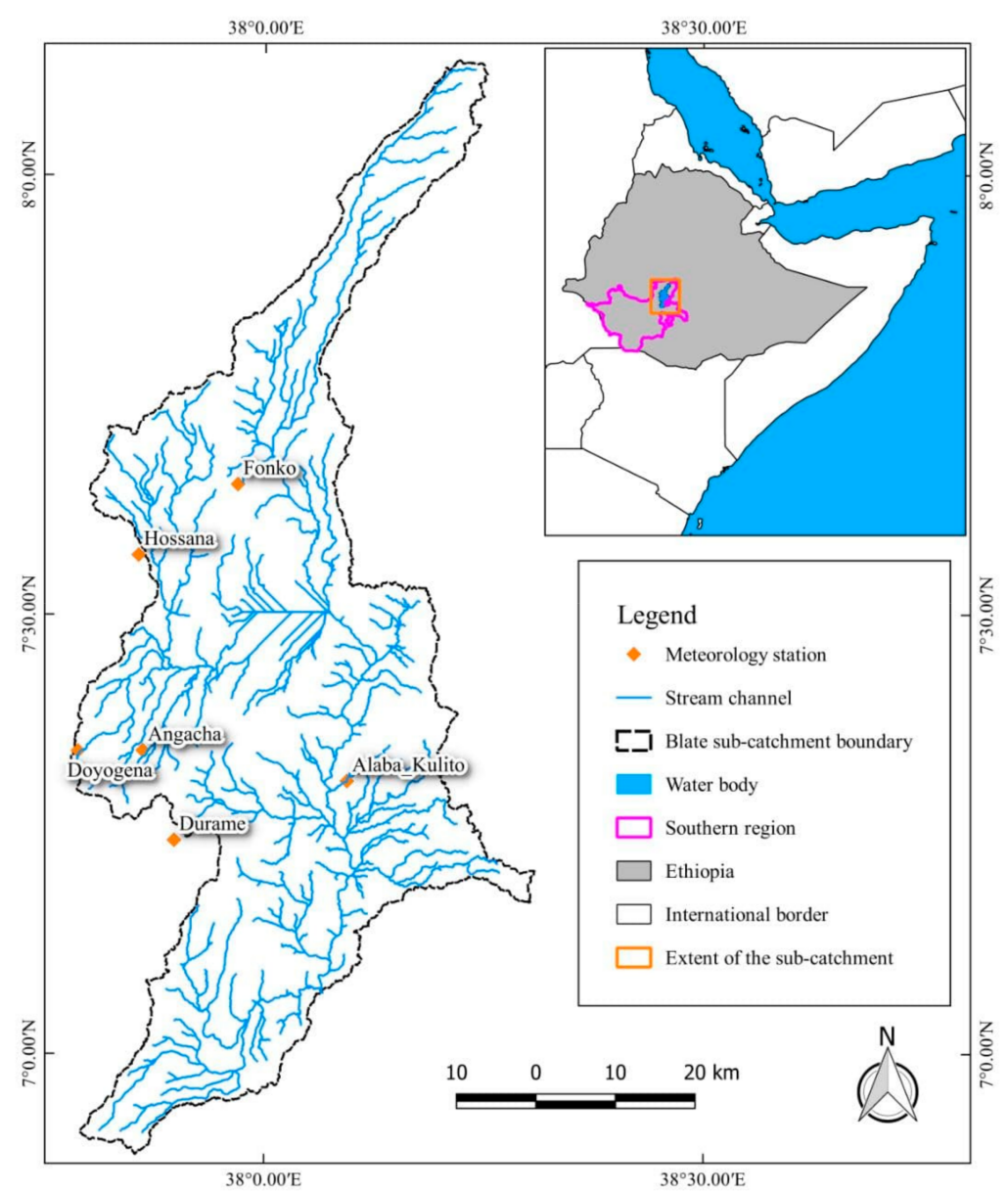

Figure 1. Map of the study area (Bilate sub-watershed) showing the drainage basin and the location of meteorological stations.

The study was conducted in the Bilate sub-watershed which is one of the inland rivers in southern Ethiopia that drains from the Abaya-Chamo drainage basin which covers $5625 \mathrm{~km}^{2}$ and the altitude of the watersheds range from 1300 to $3050 \mathrm{~m}$ above sea level [22]. The sub-watershed lies within a geographic location ranging from $6^{\circ} 53^{\prime}$ to $8^{\circ} 80^{\prime} \mathrm{N}$ latitude and from $37^{\circ} 46^{\prime}$ to $38^{\circ} 19^{\prime} \mathrm{E}$ longitude. In the study area the annual rainfall amount and temperature range from $972-1023 \mathrm{~mm}$ and $12{ }^{\circ} \mathrm{C}-25^{\circ} \mathrm{C}$ in the sub watershed respectively [22]. The area has a bimodal rainfall characteristic. The main rainy season (Kiremt) rainfall extends from mid of June to the end of September whereas the short rainy season (Belg) extends from end of February to the end of May while the dry season extends from October to beginning of February [27]. The main livelihood of the area is characterized by mixed crop-livestock farming systems where cereals, legumes, root crops, and perennial crops like enset (Ensete ventricosum) are the main crops grown in the area [38].

\subsection{Climate Data Sources}

Rainfall and temperature data for the period 1983-2016 were obtained from various sources. Daily temperature and rainfall for the selected stations and merged station-satellite gridded data were obtained from the National Meteorological Agency (NMA) of Ethiopia 
with a grid cell size of 0.05 degrees or $5.55 \mathrm{~km} \times 5.55 \mathrm{~km}$ for the period of 1983-2016. The stations were selected based on the relative completeness of data availability and the length of years that fulfills the requirements of the World Metrological Organization (WMO). It is a standard practice that a minimum of 30 years of data is required to conduct climatological studies [22]. In addition, gridded precipitation data from the study period 1983-2016 was obtained from Climate Hazard Group Infrared Precipitation with Station (CHIRPS). CHIRPS is a unique data set available on high-resolution temporal (daily) and spatial resolution $(5 \mathrm{~km})$ with quasi-global coverage and attractive to study climate extremes over the small geographical areas [39-41]. Dinku et al. [42] validated CHIRPS data over East Africa particularly in Ethiopia with reference to the rain gauge data and the performance of temporal and spatial pattern of rainfall was highly correlated. In the present study, 34 years of meteorological satellite data for the watershed is used to investigate the recent changes in extreme rainfall and temperature across the watershed (Table 1).

Table 1. Coordinates of the selected meteorological stations in the Bilate sub-watershed.

\begin{tabular}{ccccc}
\hline Name of Station & Lat. (N) & Long. (E) & Alt. (a.m.s.l) & Duration \\
\hline Doyogena & $7^{\circ} 20^{\prime}$ & $37^{\circ} 47^{\prime}$ & 2629 & $1983-2016$ \\
Angacha & $7^{\circ} 20^{\prime}$ & $37^{\circ} 51^{\prime}$ & 2321 & $1983-2016$ \\
Durame & $7^{\circ} 14^{\prime}$ & $37^{\circ} 53^{\prime}$ & 2116 & $1983-2016$ \\
Alaba Kulito & $7^{\circ} 31^{\prime}$ & $38^{\circ} 09^{\prime}$ & 1726 & $1983-2016$ \\
Hossana & $7^{\circ} 34^{\prime}$ & $37^{\circ} 51^{\prime}$ & 2306 & $1983-2016$ \\
Fonko & $\mathbf{7}^{\circ} \mathbf{3 8 ^ { \prime }}$ & $\mathbf{3 7}^{\circ} \mathbf{5 8 ^ { \prime }}$ & $\mathbf{2 2 4 6}$ & $\mathbf{1 9 8 3 - 2 0 1 6}$ \\
\hline
\end{tabular}

Before carrying out the analysis, the station data were inspected for any possible presence of temporal inconsistencies and discontinuities. It was found that most of the station-based data in the region are not continuous and do contain several missing values for both rainfall and temperature. Due to these problems, the missing values were estimated using Inverse Distance Weighted (IDW) interpolation technique which is the recommended method for estimating missing meteorological data [43]. The IDW assumes that weather stations that are close to each other are highly correlated with one another than those that are located further away. As a result, the missing values are obtained from the nearest weather station which has a relatively complete data set as the weighted average of the observed rainfall and temperature values from the nearest station [44].

The mean annual value of the merged station-satellite gridded data, obtained from NMA of Ethiopia, was compared with the station data in the watershed. To see whether there is a significant difference between the merged station-satellite gridded data and observed data in each selected station in the watershed, the F-test was computed and found that there were no significant differences between the two data sets. As result, due to the completeness and quality of data, merged station-satellite gridded data were used to undertake trend analysis instead of the gauge station data so as to avoid the missing data values that were detected in these data sets [45]. Annual rainfall and temperature data for the watershed were calculated by combining and averaging the merged station-satellite gridded data from 1983-2016 [30]. Analysis of rainfall and temperature trends for the watershed were then produced as merged values that estimated the amount of rainfall and temperature data in the particular sub-watershed unit [46].

\subsection{Data Analysis Technique}

Numerous tests are available to study the long-term change of climate parameters over time. Measuring the changes of observed climate trends and variability over time was done using different techniques which included Standardize Rainfall Anomaly Index (SRAI) to analyze the frequency and intensity of the precipitation. Coefficient of variation $(\mathrm{CV})$ was used to estimate the seasonal and annual variation of the rainfall patterns and Mann- Kendall (MK) trend test to detect climate trend in times series data and Standard 
Precipitation Index (SPI) to quantify the rainfall deficiency of the observed time scale in the given watershed $[28,38,47,48]$.

\subsubsection{Standard Anomaly Index (SAI)}

The SAI was used to calculate the negative and positive anomalies of rainfall fluctuations in a certain region. It helps to identify the drought period through determining the dry and wet years of the recording period [28,34,49-51]. This index is calculated using equation 1 given below:

$$
\mathrm{Z}=\frac{(X i-\bar{X} i)}{S}
$$

where $\mathrm{Z}$ is standardized rainfall anomaly; $x_{i}$ is the annual rainfall for the historical record; $\overline{x i}$ is the mean of annual rainfall and $s$ is the standard deviation of the annual rainfall for the historical observation of the time series.

According to Agnew and Chappel [49], classification of drought severity, extreme drought $(Z<-1.65)$, severe drought class $(-1.28>Z>-1.65)$, moderate drought class $(Z>-0.84)$. Standardized rainfall anomaly index spans $<-2$ (dry) and $>2$ (wet) that indicates extreme drought and an extreme wet year respectively $[52,53]$.

\subsubsection{Coefficient of Variation (CV)}

$\mathrm{CV}$ was employed to detect the seasonal and annual rainfall variability for the observation period. As documented by Hare [54], the degree of rainfall variability is classified as high $(C V>30)$, moderate $(20<C V>30)$ and low $(C V<20)$. Hence the higher the value of $\mathrm{CV}$ the higher the variability of rainfall in the study region and the reverse is also true. The value of $C V$ can be computed using Equation (2):

$$
\mathrm{CV}=\frac{\sigma}{\mu} \times 100
$$

where $\mathrm{CV}$ is the coefficient of variation, $\sigma$ is the standard deviation and $\mu$ is the mean precipitation of the recording period.

\subsubsection{Precipitation Concentration Index (PCI)}

PCI was used to evaluate the distribution of the monthly, seasonally and annual distribution of rainfall. PCI is used to indicate the hydrological risks of floods and drought occasions in the study area $[55,56]$ and can be calculated using Equation (3) below:

$$
P C I=\frac{\sum_{i=1}^{12} p i^{2}}{\left(\sum_{i=1}^{12} P i\right)^{2}}
$$

where $P_{i}$ is monthly precipitation in the month i PCI.

The PCI value of $<10$ represents uniform distribution of precipitation; PCI value ranging from 11-15 indicates moderate rainfall concentration; PCI value ranging 16-20 represents the irregular distribution of rainfall in the area and any value which is above 20 unit shows a strong irregular rainfall distribution across the area [57].

\subsubsection{Standard Precipitation Index (SPI)}

The SPI is the most widely used method of drought index to detect and characterize meteorological drought [52,58]. SPI can be calculated for the different periods $(1,3,6,12$, 24, and 48 months) [47]. In this study, 12 months or annual periods (SPI-12) was used. SPI value was calculated by using Equation (4):

$$
\text { SPIij }=\frac{X i j-\mu i j}{\alpha i j}
$$

where the SPIij represents an ith month at jth period, $\mathrm{Xij}$ is the observed rainfall total value for the ith month at the jth period, $\mu \mathrm{ij}$ and $\alpha \mathrm{ij}$ represents the long-term mean and standard 
deviation of the ith month and jth timescale of the selected period respectively. The study conducted by McKee et al. [52] and Svoboda [47], SPI has different output values ranging from -2.0 to 2.0 (Table 2)

Table 2. Standard Precipitation Indices (SPI) and their interpretation.

\begin{tabular}{cc}
\hline SPI Value & Interpretation \\
\hline 1.5 to 1.99 & Extremely wet \\
1.0 to 1.49 & Severely wet \\
0.99 to -0.99 & Moderately wet \\
-1.0 to -1.49 & Near normal \\
-1.5 to -1.49 & Moderately dry \\
$\leq-\mathbf{2 . 0}$ & Severely dry \\
\hline
\end{tabular}

\subsubsection{Mann- Kendall (MK)}

The MK trend test is one of the widely used methods to detect climate trend in times series data. The details of the MK test are provided in $[59,60]$. The MK test is used to detect monotonically (increasing or decreasing) trends of annual and seasonal bases of climate parameters. To investigate the existence of long-term change for both rainfall and temperature indices, Mann- Kendall (MK) trend test and Sen's estimator were employed. Annual and seasonal trend change detection with the MK test is less affected by climate outliers [61,62]. However, the result of the MK test may contain some error if auto correlation exists in the time series data. To overcome this problem, the pre-whitening procedure was performed and there was no significant level of serial autocorrelation at all lags and performed without any modification. Following the serial autocorrelation test, the MK test from the $Z$ value and trend from Sen's slope $(\beta)$ estimation was computed based on monthly, seasonal, and annual rainfall data from 1983-2016 in the Bilate watershed, and the results are presented in Table 3.

Table 3. Summary statistics and MK trend test output for the Bilate Watershed (1983-2016).

\begin{tabular}{|c|c|c|c|c|c|c|c|}
\hline Variables & $\operatorname{Mean}(\mathrm{mm})$ & $\mathrm{SD}(\mathrm{mm})$ & CV (\%) & Sen.'s $(\beta)$ & $\begin{array}{l}\text { MK Test } \\
(p \text {-Value) }\end{array}$ & $\begin{array}{l}\text { Rainfall Trends } \\
\text { Contribution (\%) }\end{array}$ & \\
\hline January & 15.02 & 16.53 & 110.04 & -0.026 & 0.667 & 1.47 & $\mathrm{D}$ \\
\hline February & 27.51 & 31.26 & 113.66 & -0.720 & $0.100 *$ & 2.69 & $\mathrm{D}$ \\
\hline March & 69.27 & 40.42 & 58.35 & -0.838 & 0.346 & 6.77 & $\mathrm{D}$ \\
\hline April & 115.97 & 49.91 & 43.04 & -0.304 & 0.659 & 11.33 & $\mathrm{D}$ \\
\hline May & 126.97 & 50.33 & 39.64 & -0.129 & 0.859 & 12.41 & $\mathrm{D}$ \\
\hline Jun & 109.79 & 32.05 & 29.19 & 0.807 & 0.215 & 10.73 & I \\
\hline July & 160.74 & 31.11 & 19.35 & 0.406 & 0.289 & 15.71 & I \\
\hline August & 162.57 & 30.33 & 18.66 & 0.000 & 1.000 & 15.89 & I \\
\hline September & 134.26 & 28.15 & 20.97 & 0.844 & $0.054^{* *}$ & 13.12 & I \\
\hline October & 66.30 & 53.16 & 80.19 & -0.080 & 0.977 & 6.48 & $\mathrm{D}$ \\
\hline November & 21.18 & 25.58 & 120.78 & 0.595 & $0.015^{* * *}$ & 2.06 & I \\
\hline December & 13.67 & 23.78 & 173.97 & -0.046 & 0.532 & 1.34 & $\mathrm{D}$ \\
\hline Belg & 339.72 & 97.00 & 28.55 & -1.843 & $0.027 * *$ & 33.20 & $\mathrm{D}$ \\
\hline Kiremt & 567.36 & 78.99 & 13.92 & 2.220 & 0.156 & 55.45 & I \\
\hline Bega & 116.17 & 69.75 & 60.04 & 0.680 & 0.444 & 11.35 & I \\
\hline Annual & 1023.24 & 142.0 & 13.94 & 1.136 & 0.702 & 100.00 & I \\
\hline
\end{tabular}




\section{Results and Discussion}

\subsection{Rainfall Summary Statistics}

The computed summary statistics of rainfall including mean, standard deviation (SD) rainfall distribution, and CV over the study area for the period 1983-2016 are presented in Table 3. The mean annual rainfall was recorded as $1023.24 \mathrm{~mm}$ with a standard deviation of $142.60 \mathrm{~mm}$. The two months with the highest maximum monthly rainfall are July $(160.74 \mathrm{~mm})$ and August $(162.57 \mathrm{~mm})$ which contributed $15.71 \%$ and $15.89 \%$ to the total rainfall respectively. December and February received the least rainfall and contributed $1.34 \%$ and $1.47 \%$ to the annual rainfall respectively. The major share of the annual rainfall was received in Kiremt (rainy season) (55.45\%) and Belg (planting season) (33.20\%). The lowest amount of rainfall was received in the short rainy season (Bega) which lasts between November to January and contributed $11.35 \%$.

\subsection{Linear Trend Analysis of Annual and Seasonal Rainfall}

The MK trend test showed that there was a statically significant increasing trend for the month of September and November at a $5 \%$ and $1 \%$ level of significance respectively (Table 3). While a significant decreasing trend was observed in February. There was no significant increase in rainfall trend that was observed in June and July whereas no significant decreasing trend was observed in March, April, and May. The monthly share of rainfall exhibited about $57.51 \%$ positive trend and $42.49 \%$ negative trend in rainfall amounts. On the other hand, Belg exhibited a decreasing trend at a $5 \%$ level of significance. The spatial trend analysis for each station (not shown here) also confirms a consistent pattern with the area-averaged trend analysis for the watershed, which is a declining trend of the Belg rainfall in the region. Kiremt, Bega, and annual rainfall have shown nonsignificant increasing trends. The result is consistent with the findings of other studies that observed non-significant change in annual and Kiremt rainfall over Ethiopia $[15,32,53,63]$. The rate of change of the annual rainfall variability was recorded as $0.474 \mathrm{~mm} /$ year while the trend of annual rainfall was found to be statistically insignificant. These results are in agreement with the findings made by Benti and Abara [27] who examined the trends of annual rainfall distribution in southern Ethiopia and noted that the annual rainfall had a statistically insignificant increasing trend since 1995-2014.

Seasonal trends are shown in Figure 2 the seasonal rainfall variability for Belg, Kiremt, and Bega seasons was $-1.935 \mathrm{~mm} /$ year, $1.841 \mathrm{~mm} /$ year and $0.568 \mathrm{~mm} /$ year respectively. whereas the declining trend of Belg season was statistically significant (Table 3). The negative and positive values indicated decreasing and increasing pattern of rainfall distribution over the observed period respectively. As depicted in Figure 2, Belg rainfall showed a decreasing trend and significant at $(p<0.05$ level). The Belg season rainfall is crucial for the farmers as the season determines the preparation and planting activities of the farmers in the study area.

The observed decreasing trend of the Belg rainfall might be caused by the atmosphericoceanic processes that influence rainfall in the region. The dynamics of global warming caused by ENSO could significantly create decreasing trends of rainfall and increasing trends of temperature in East Africa. A $1{ }^{\circ} \mathrm{C}$ increase of annual temperature in El Niño 3.4 SST region could decrease about $79 \mathrm{~mm} /$ year, particularly in East Africa [64]. Following such dry conditions, possible adaptation and mitigation measures such as conservation agriculture and climate-smart options should be put in place $[65,66]$.

The annual and seasonal patterns of rainfall analysis was computed using the regression model (Figure 2) and the results are summarized in Table 4. The annual and seasonal coefficient of variation computation indicate that there was a significant seasonal rainfall variation observed at $p<0.05$ level of significant (Table 4). However, annual rainfall variations showed a non-significant increase in trend and the average rate of change of the rainfall variation was calculated as $0.47 \mathrm{~mm} /$ year (Figure 3). According to Cheung et al. [30], there were no significant changes in annual rainfall trends at the national and watershed levels in Ethiopia. The study conducted by Ayalew et al. [26] on rainfall vari- 
ability and its current trends revealed that long-term patterns of rainfall did not show significant decreasing or increasing trends but the early end of rainfall distribution has been experienced in the recently. Decadal annual mean rainfall for 1984-1994, 1995-2005, and 2006-2016 was recorded as $972.59 \mathrm{~mm}, 1082.39 \mathrm{~mm}$, and $1021.53 \mathrm{~mm}$ respectively. This shows that from 1995 to 2016, rainfall pattern had a decreasing trend and the average deficiency of rainfall since $1995-2016$ was about $60.86 \mathrm{~mm}$ per year and result concur with findings of recent studies made in Ethiopia and east Africa region $[67,68]$.

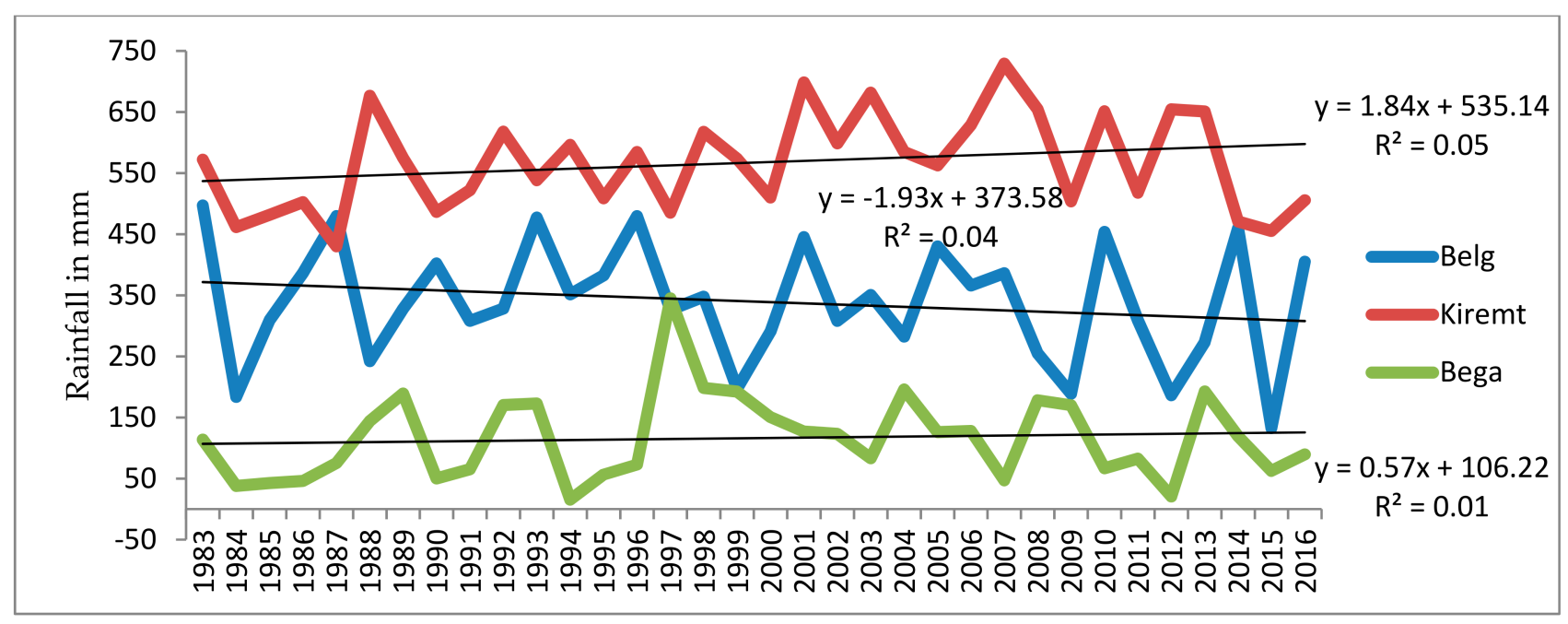

Figure 2. Seasonal rainfall trends over the observed period for 1983-2016.

Table 4. Linear regression result of seasonal precipitation (1983-2016).

\begin{tabular}{ccccccc}
\hline Season & $\begin{array}{c}\text { Change in } \\
\text { Rainfall/mm/Year }\end{array}$ & $\boldsymbol{p}$-Value & $\mathbf{R}^{\mathbf{2}}$ & Mean (mm) & CV & $\begin{array}{c}\text { \% of Annual } \\
\text { Rainfall }\end{array}$ \\
\hline Kiremt & 1.841 & 0.156 & 0.054 & 567.36 & 13.92 & 55.45 \\
Belg & -1.935 & 0.027 & 0.039 & 339.72 & 28.55 & 33.20 \\
Bega & 0.568 & 0.444 & 0.006 & 116.17 & $\mathbf{1 0 2 3 . 2 4}$ & $\mathbf{1 3 . 9 4}$ \\
\hline Annual & $\mathbf{0 . 4 7 4}$ & $\mathbf{0 . 7 2}$ & $\mathbf{0 . 0 0 1}$ & $\mathbf{1 0 0}$ \\
\hline
\end{tabular}

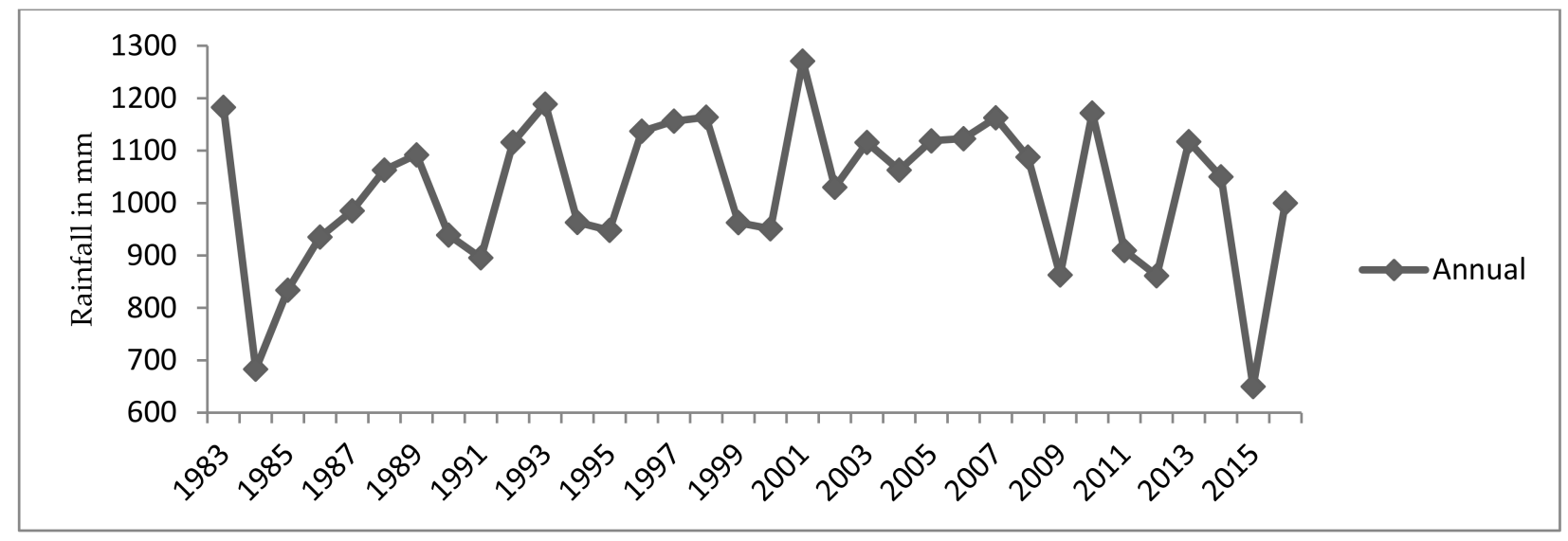

Figure 3. Annual trend of rainfall between 1983-2016.

The rainfall in the study area occurs in the Kiremt and Belg season. The monthly rainfall anomaly was computed to identify the anomalous dry and wet periods in the observed time scale. The monthly anomalies findings are presented in Figure 4. The main rainy season Kiremt (summer) rainfall starts from June to September while the small rainy 
season Belg (Spring) begins from February to May. As shown in Figure 4, the rainfall anomaly index result captured the seasonal rainfall distribution for both Kiremt and Bega rains which experiences unpredictable and irregular rainfall patterns and affects both crop and livestock production [15].

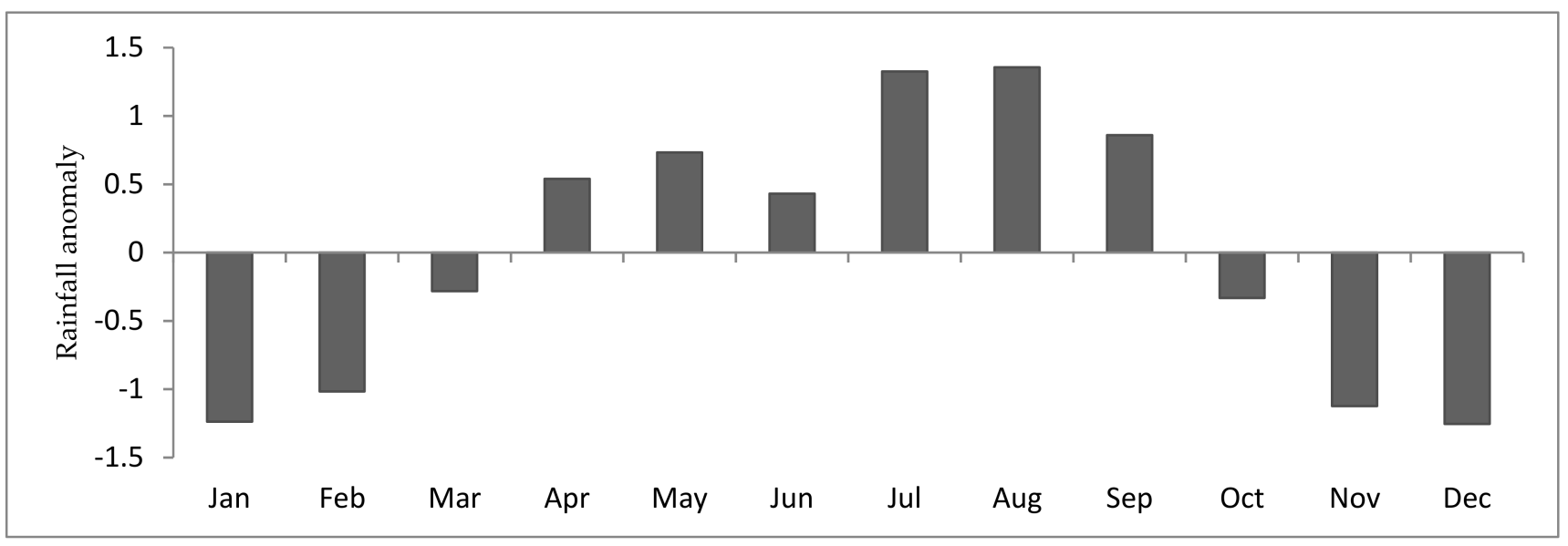

Figure 4. Standardized rainfall anomalies from a monthly mean calculated for all years and seasons (1983-2016).

The study region experienced high seasonal rainfall variability from below to aboveaverage rainfall distribution. This variability may be attributed to the seasonal movement of the inter-tropical convergent zone (ITCZ) and warm and cold ENSO episodes (El Niño/La Niña) event [69].

\subsection{Spatial and Temporal Variability of Rainfall}

The coefficient of variation (CV) of the seasonal rainfall revealed a high $(60.04 \%)$ and moderate (28.55\%) rainfall variability during Bega and Belg seasons respectively (Table 3). On the other hand, annual rainfall had less coefficient of variation, shown that interannual rainfall (13.94\%) variability was observed during 1983-2016 in the study area. Similarly, the months of July, August, September had less rainfall variation and the remaining months experienced high rainfall variation (See Table 3). This is consistent with the recent studies $[28,38,70]$, which identified a strong variability and unpredictability of the seasonal and annual trends of climate in Ethiopia. The annual rainfall anomalies from 1983-2016 in the study area are presented in Figure 5. The standard rainfall anomalies were computed and the result indicated that there were positive and negative anomalies, which implied the presence of inter-annual rainfall variability across the observed time series. The highest positive anomaly (+1.74) was observed in the year 2001 and the highest negative anomaly (-2.62) was observed in the year 2015. The year 2015 experienced the highest negative anomaly due to the occurrence of the El Niño which affected the main livelihood of the rural people in different parts of Ethiopia [69]. Recent literature indicated that about twelve extreme historical droughts have been recorded in Ethiopia and affected the economic development of the country $[14,15,53,71]$.

The drought incidents in Ethiopia negatively affected the livelihoods of millions of people. The major droughts in Ethiopia ecorded in the last three decades were related to ENSO events. In Ethiopia, El Niño events in 1987, 1991, 2001, 2009, and 2015 coincided with an extended drought condition from April to November which covers the main cropping season of the country. The annual rainfall anomaly was computed and drought years in the study region detected negative anomalies of 1984, 1985, 1986, 1987, 1990, 1991, 1994, $1997 / 8,1999,2000,2009,2011,2012,2015,2016$ which are coinciding with the El Niño events. The results are supported by the recent studies on the effect of El Niño events on Ethiopian rainfall distribution and its outcomes [34]. The recent 2015 El Niño related drought reduced annual household consumption by $8 \%$ and this created poor resilient systems among rural communities in Ethiopia [72]. 


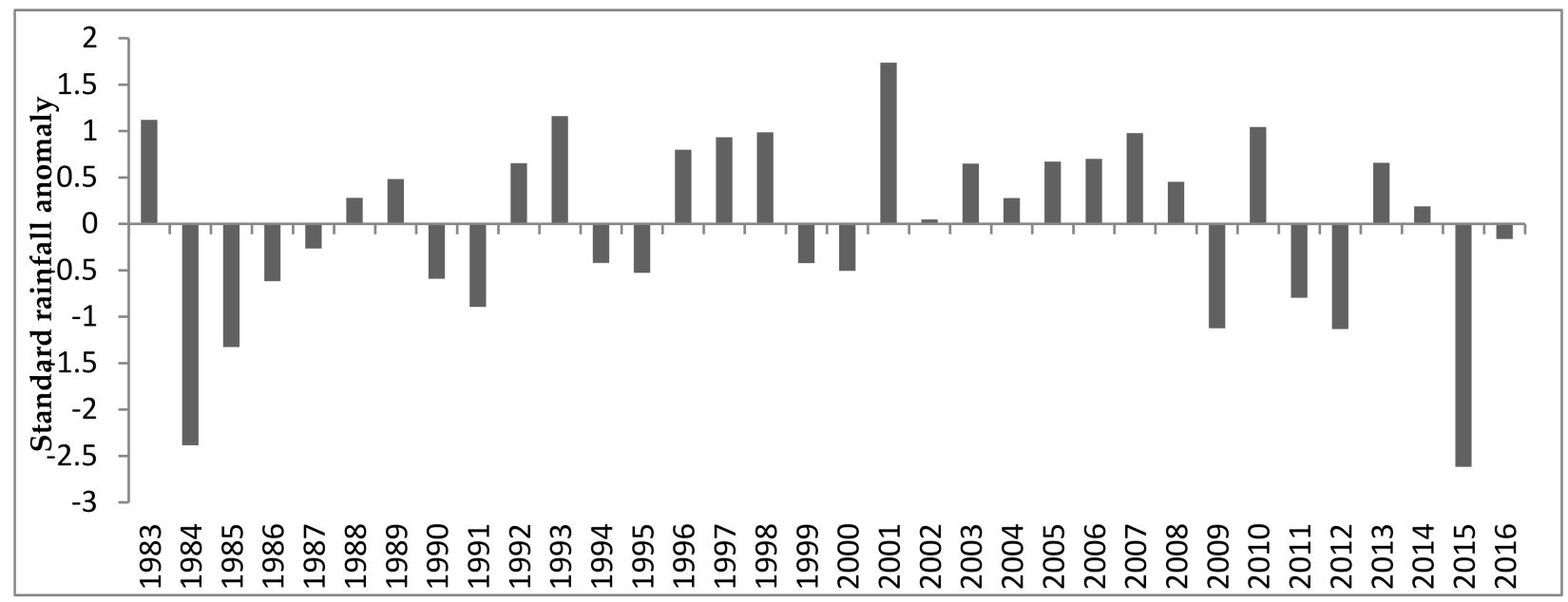

Figure 5. Standard annual rainfall anomalies of the watershed (1983-2016).

Precipitation Concentration Index was calculated based on a different class of PCI to measure the distribution of rainfall on a seasonally and annual basis over the watershed (Table 5). As presented in Table 5,94\% of the studied period experienced moderate rainfall distribution and about $6 \%$ of the rainfall distribution was irregular.

Table 5. Years of the different PCI class in the study watershed (1984-2016).

\begin{tabular}{ccccc}
\hline PCI & Categories & Years & Percentage & Seasons \\
\hline$<10$ & Uniform rainfall distribution & $1(2007)$ & 2.94 & Kiremt $(\mathrm{PCI}=8.76)$ \\
Between 10 and 15 & Moderate rainfall distribution & 31 & 91.18 & Belg $(\mathrm{PCI}=12.09)$, \\
Between 16 and 20 & An irregular rainfall distribution & $2(1984,2012)$ & 5.88 & Annual $(\mathrm{PCI}=13.17)$ \\
$>\mathbf{2 0}$ & Strong erratic rainfall distribution & $\mathbf{0}$ & $\mathbf{0}$ & \\
\hline
\end{tabular}

The annual mean precipitation concentration index revealed a moderate rainfall distribution experienced in the study sub-watershed and the dry season had an irregular rainfall distribution compared with the wet seasons in the study area (Table 5).

\subsection{Analysis of Drought in the Watershed}

The results of the SPI values for the watershed are presented in Figure 6. The area experienced wet to extremely dry years. For instance, wet (1.5 to 1.99) year was experienced in 2001 and moderately wet (1.0 to 1.49) years were experienced in 1983, 1993, and 2011. On the other hand, moderate dry $(-1.0$ to -1.49$)$ year was observed in 1985,2009 and 2012 whereas extreme dry $(\leq-2.0)$ years were recorded in the 1984 and 2015. The rest of the years in the watershed exhibited under below normal rainfall distribution. The result agrees with the recent studies that the frequency of the drought cycle has been changing over time in Ethiopia [29,73].

From the SPI findings presented in Figure 6, it is evident that most of the drought years were associated with the El Nino events whereas wet years coincided with La Nina years. For example, the recent 2015 year caused by the El Nino event was considered as one of the driest years in the history of Ethiopia, and the Belg and Kiremt seasons were highly affected. As result, crops failed in the field, livestock died and millions of people have remained food insecure [25,53,74].

The monthly SPI was analyzed and the results are depicted in Figure 7. The SPI-1month value identified as the wet and drought month's happened in the study area and it is showing the variation of rainfall distribution across the watershed. The driest months were observed in April 1984, July 1987, August 1986, May 1989, Jun 1995, March 2000, Jun 
2014, April, and June 2015. These dry months with respective years are concurring with the drought history of Ethiopia caused by the El Niño event [72].

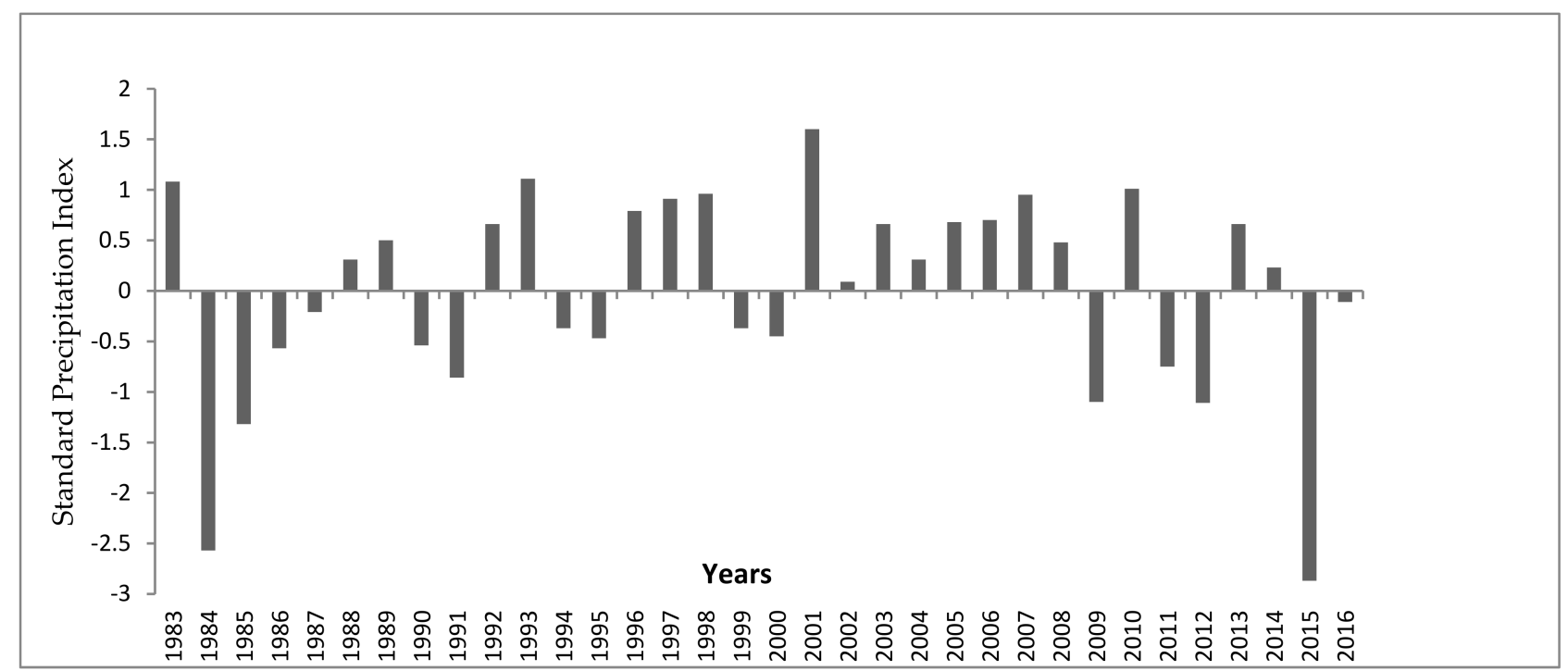

Figure 6. Standard Precipitation Index (SPI) for Annual rainfall series (1984-2016).

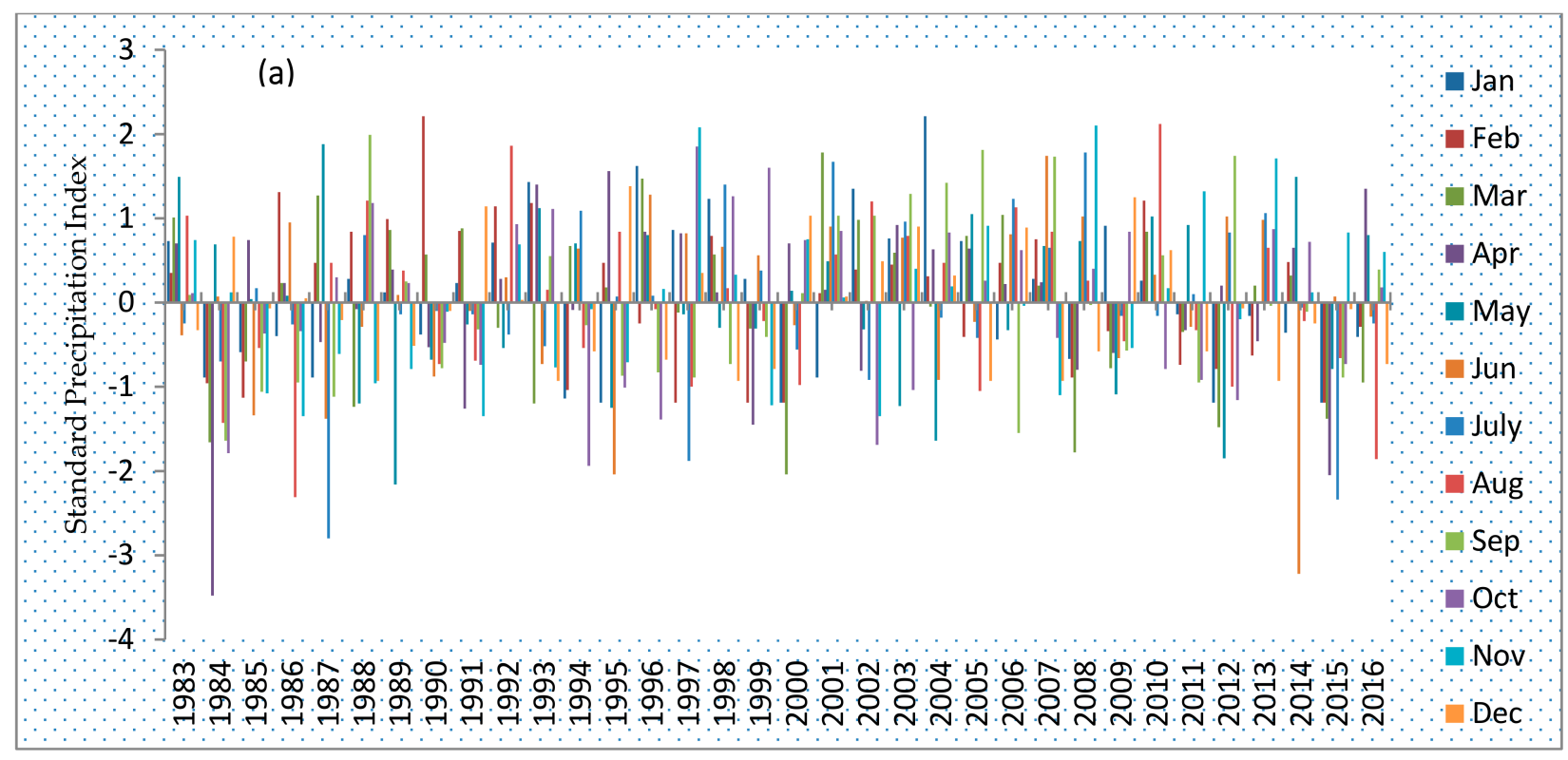

Figure 7. Standard precipitation index (SPI) result for monthly time scales in the watershed.

The 2015 drought year occurred in East Africa affecting Ethiopia caused by the El Nino event affected Belg (March, April, May), and Kiremt (June, July, August, and September) seasons which were received below normal rainfall, and this was also experienced in northern and southern eastern Ethiopia [53]. Following such drought years, both crop livestock production were highly affected in this period and this was due to the fact that the Belg and Kiremt seasons are considered as the main cropping seasons in most part of Ethiopia. On the other hand the historical monthly SPI value in Figure 7 indicate that excess rainfall distribution were observed in February 1990, December 1989 and 2002, November 1997, 2008, and August 2010 [25]. 


\subsection{Analysis of Temperature Trends}

The mean annual temperature in the study area for the period was $18.8^{\circ} \mathrm{C}$ and the mean maximum and mean minimum temperature were $25.2^{\circ} \mathrm{C}$ and $12.4^{\circ} \mathrm{C}$ respectively (Figure 8). Decadal analysis of the mean maximum temperatures from 1983 to 1993,1994 to 2005 , and 2006 to 2016 was as $24.97^{\circ} \mathrm{C}, 25.17^{\circ} \mathrm{C}$, and $25.49^{\circ} \mathrm{C}$ while the mean minimum temperatures were $11.64{ }^{\circ} \mathrm{C}, 12.42{ }^{\circ} \mathrm{C}$, and $12.83{ }^{\circ} \mathrm{C}$ respectively. This analysis showed significant $(p<0.05)$ increasing trends for both mean maximum and minimum temperature in the study area. The rate of increase for mean annual, maximum and minimum temperature was as $0.042{ }^{\circ} \mathrm{C} / \mathrm{yr}, 0.027^{\circ} \mathrm{C}$, and $0.056{ }^{\circ} \mathrm{C}$ per year respectively (Figure 8).
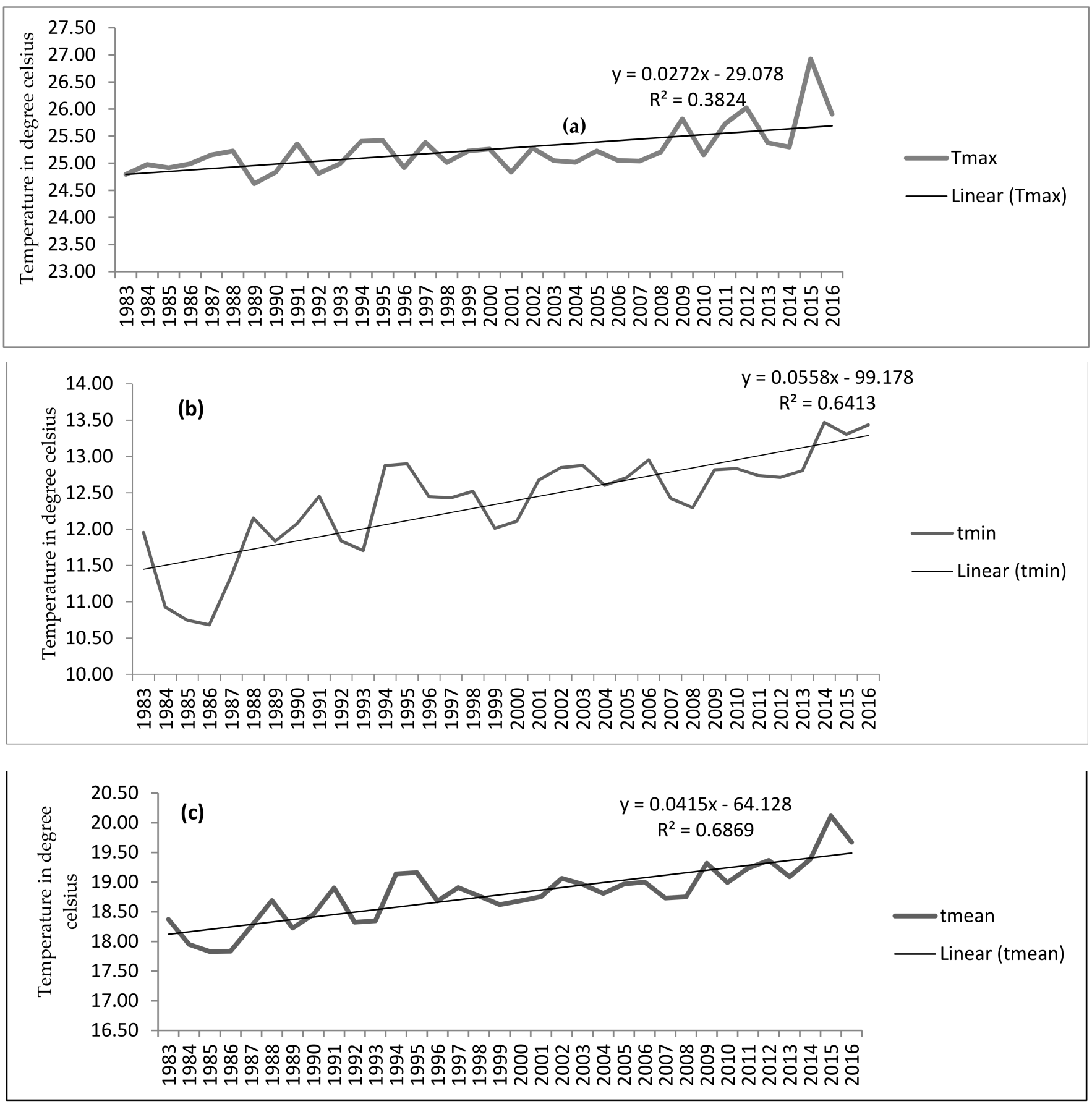

Figure 8. Annual variations of Temperature trends for (a) Maximum, (b) Minimum and (c) Mean over the study area (1983-2016). 
The minimum temperature increase trend was greater than max temperature trend of the study area for the last 34 years (Figure 8). These findings are similar to studies in the region that, have showed that there has been an increasing trend in the average annual temperature $[10,75]$, and annual maximum and minimum temperature $[27,28]$ in Ethiopia. The increasing temperature and decreasing precipitation in the country has devastating effects on crop farmers because $80 \%$ of the country's population is farmers who are depending on rain fed agriculture [75]. Additionally, climate projections suggest that the annual temperature trends would be higher in the future. Thus there is need to develop adaptation and mitigation measures in the various sectors of the economy specifically agriculture, water, energy and health.

\section{Summary and Conclusions}

This study comprehensively analyzed temporal variability and the monotonic trend of rainfall distribution in southern Ethiopia. The study area has two rainfall seasons, Kiremt and Belg. Kiremt is the main rainy season which accounts for $55 \%$ of the annual rainfall, and Belg contributes 32\%. The annual mean rainfall in the region was $1023.24 \mathrm{~mm}$ with the standard deviation and coefficient of variation $142.60 \mathrm{~mm}$ and $19.94 \%$ respectively. The coefficient of variation and precipitation concentration index showed rainfall variability and irregular distribution.

Large variation was observed among seasons in the observing period. The SAI and SPI indices showed similar drought years with the proportions of years with below and above average rainfall distribution anomalies of $55.90 \%$ and $44.10 \%$ respectively. The Mann Kendall trend analysis result revealed an increasing trend for annual Kiremt and Bega seasons whereas the Belg season significantly declined (at $p<0.05$ significance level). The rate of change for annual mean, maximum and minimum temperature in the study area was $0.042{ }^{\circ} \mathrm{C}, 0.027{ }^{\circ} \mathrm{C}$, and $0.056^{\circ} \mathrm{C}$ respectively. Accordingly, decadal mean rainfall amount from 1984-1994, 1995-2005, and 2006-2016 was recorded as $972.59 \mathrm{~mm}, 1082.39 \mathrm{~mm}$, and $1021.53 \mathrm{~mm}$ respectively. This clearly shows a decreasing rainfall trend from 1995 to 2016, was about $60.86 \mathrm{~mm}$ per year. This reduction of rainfall in the study area could harm crop production, forage production for the livestock feed, and food security. Decadal analysis of the mean maximum and mean minimum temperature from 1983 to 1993, 1994 to 2005, and 2006 to 2016 was calculated as $24.97^{\circ} \mathrm{C}, 25.17^{\circ} \mathrm{C}$, and $25.49^{\circ} \mathrm{C}$ for maximum temperature and $11.64{ }^{\circ} \mathrm{C}, 12.42{ }^{\circ} \mathrm{C}$, and $12.83^{\circ} \mathrm{C}$ for minimum temperature for the last three decades respectively. This analysis confirms increasing trends for both mean maximum and mean minimum temperature in the study area. The increasing temperature over the study areas create severe water loss due to evaporation and this affects agriculture and livestock production, domestic water supply, and municipal services. The study concludes that there was a significant variation of rainfall and temperature through the observing period. Rainfall variation could cause flooding and outbreak of human and livestock diseases and conservation agriculture practice is imperative for overcoming the problem. The study also found that the SAI and SPI result are consistent with the drought years in the past which has been linked with the ENSO event. The study revealed that extreme flooding and drought mitigation measures in the study area should be implemented. In addition, the study recommends the provision of timely and accurate climate information such as seasonal forecasts, early warning systems and this requires a holistic understanding of the impact of climate change on smallholder farmers' livelihoods. Therefore, this study calls for policy-driven actions to overcome the challenges of climate-changing impact by transforming the climate-sensitive livelihood systems into climate-smart options. We also recommend future studies to expand the geographical area that includes the entire southern regions.

Author Contributions: A.B.: Conceptualization, data collection, statistical analysis, and writingoriginal draft preparation. T.D.: Conceptualization, investigation, data collection, statistical analysis support, writing-review and editing. J.W.R.: Conceptualization, investigation, analysis support, writing review and editing. C.O.: Conceptualization, investigation supervision, writing-review and 
editing. P.M.O.: Funding acquisition, supervision, writing-review and editing. L.A.O.: Conceptualization, investigation, supervision, writing—review and editing. Z.B.: Supervision, writing-review and editing. All authors have read and agreed to the published version of the manuscript. D.S.: Funding acquisition, writing-review and editing.

Funding: This research was financially supported through CCAFS-EC grant reference: 2000002575 for the project on Building Livelihoods and Resilience to Climate Change in East and West Africa: Agricultural Research for Development (AR4D) for large-scale implementation of Climate-Smart Agriculture. The funds are administered by the International Fund for Agricultural Development (IFAD), Rome Italy while the project is implemented by Alliance Bioversity-CIAT. This study was also financially supported through a grant from the World Bank "Accelerating Impacts of CGIAR Climate Research for Africa (AICCRA)" ESA regional project (Grant No. D7540) signed between CIAT and the International Development Association (IDA). Additional fieldwork support was provided by the Swedish International Development Agency (SIDA) through the Stockholm Environment Institute (SEI) Regional Engagement Fund for Africa"and the Deutscher Academischer Austaushdenist (DAAD) through World Agroforestry Center (ICRAF).

Institutional Review Board Statement: The study was conducted according to the guidelines of the Declaration of Helsinki and approved by the Institutional Review Board (or Ethics Committee) of the International Livestock Research Institute (ILRI), on 19 March 2018.

Informed Consent Statement: Informed consent was obtained from all subjects involved in the study in Bilate sub-watershed, Southern National Nationalities and Peoples Region (SNNPR), Ethiopia.

Data Availability Statement: The data presented in this study are available on request from the corresponding author. The data are not publicly available due to confidentiality requirements of the funding organisations for the project.

Acknowledgments: We would like to thank the Ethiopian National Meteorological Agency for providing the required climate data. We would like also to thanks Habitamu Taddese for producing the study area map.

Conflicts of Interest: The authors declare no conflict of interest.

\section{References}

1. Abidoye, B.O.; Odusola, A.F. Climate change and economic growth in Africa: An econometric analysis. J. Afr. Econ. 2015, 24, 277-301. [CrossRef]

2. Field, C.B. Climate Change 2014-Impacts, Adaptation and Vulnerability: Regional Aspects; Cambridge University Press: Cambridge, UK, 2014.

3. Reidmiller, D.; Avery, C.; Easterling, D.; Kunkel, K.; Lewis, K.; Maycock, T.; Stewart, B. Fourth national climate assessment, Impacts, risks, and adaptation in the United States; US Global Change Research Program: Washington, DC, USA, 2018 ; Volume 2.

4. Saroar, M.M.; Leal Filho, W. Adaptation through climate smart agriculture: Status and determinants in coastal Bangladesh. In Climate Change Adaptation, Resilience and Hazards; Springer: Cham, Switzerland, 2016; pp. 157-178.

5. Duyck, S. The Paris climate agreement and the protection of human rights in a changing climate. Yearb. Int. Environ. Law 2015, 26, 3-45. [CrossRef]

6. Dimitrov, R.S. The Paris agreement on climate change: Behind closed doors. Glob. Environ. Politics 2016, 16, 1-11. [CrossRef]

7. Mesfin, D.; Simane, B.; Belay, A.; Recha, J.W.; Schmiedel, U. Assessing the Adaptive Capacity of Households to Climate Change in the Central Rift Valley of Ethiopia. Climate 2020, 8, 106. [CrossRef]

8. Amare, A.; Simane, B. Assessment of Household Food Security in the Face of Climate Change and Variability in the Upper Blue-Nile of Ethiopia. J. Agric. Sci. Technol. B 2017, 7, 285-300.

9. Gebrechorkos, S.H.; Hülsmann, S.; Bernhofer, C. Changes in temperature and precipitation extremes in Ethiopia, Kenya, and Tanzania. Int. J. Climatol. 2019, 39, 18-30. [CrossRef]

10. Abebe, G. Long-term climate data description in Ethiopia. Data Brief 2017, 14, 371-392. [CrossRef]

11. Abebe, T. Climate change and development adaptation measures in Ethiopia. Econ. Focus (Addis Ababa Ethiop.) 2008, 11, 15-24.

12. Diro, G.; Tompkins, A.; Bi, X. Dynamical downscaling of ECMWF Ensemble seasonal forecasts over East Africa with RegCM3. J. Geophys. Res. Atmos. 2012, 117, D16103. [CrossRef]

13. Rowell, D.P.; Booth, B.B.; Nicholson, S.E.; Good, P. Reconciling past and future rainfall trends over East Africa. J. Clim. 2015, 28, 9768-9788. [CrossRef]

14. Mersha, A.A.; van Laerhoven, F. The interplay between planned and autonomous adaptation in response to climate change: Insights from rural Ethiopia. World Dev. 2018, 107, 87-97. [CrossRef]

15. Matewos, T. Climate Change-Induced Impacts on Smallholder Farmers in Selected Districts of Sidama, Southern Ethiopia. Climate 2019, 7, 70. [CrossRef] 
16. Arndt, C.; Robinson, S.; Willenbockel, D. Ethiopia's growth prospects in a changing climate: A stochastic general equilibrium approach. Glob. Environ. Chang. 2011, 21, 701-710. [CrossRef]

17. Mideksa, T.K. Economic and distributional impacts of climate change: The case of Ethiopia. Glob. Environ. Chang. 2010, 20, 278-286. [CrossRef]

18. Gebreegziabher, Z.; Stage, J.; Mekonnen, A.; Alemu, A. Climate Change and the Ethiopian Economy: A Computable General Equilibrium Analysis; Resources for the Future: Washington, DC, USA, 2011.

19. Zewdu, E.; Hadgu, G.; Nigatu, L. Impacts of climate change on sorghum production in North Eastern Ethiopia. Afr. J. Environ. Sci. Technol. 2020, 14, 49-63.

20. Urgessa, G.K. Spatial and temporal uncertainty of rainfall in arid and semi-arid areas of Ethiopia. Sci. Technol. Arts Res. J. 2013, 2, 106-113. [CrossRef]

21. Tierney, J.E.; Smerdon, J.E.; Anchukaitis, K.J.; Seager, R. Multidecadal variability in East African hydroclimate controlled by the Indian Ocean. Nature 2013, 493, 389-392. [CrossRef]

22. Wodaje, G.G.; Eshetu, Z.; Argaw, M. Temporal and spatial variability of rainfall distribution and evapotranspiration across altitudinal gradient in the Bilate River Watershed, Southern Ethiopia. Afr. J. Environ. Sci. Technol. 2016, 10, 167-180.

23. Minda, T.T.; van der Molen, M.K.; Struik, P.C.; Combe, M.; Jiménez, P.A.; Khan, M.S.; de Arellano, J.V.-G. The combined effect of elevation and meteorology on potato crop dynamics: A 10-year study in the Gamo Highlands, Ethiopia. Agric. For. Meteorol. 2018, 262, 166-177. [CrossRef]

24. Dubache, G.; Ogwang, B.A.; Ongoma, V.; Islam, A.R.M.T. The effect of Indian Ocean on Ethiopian seasonal rainfall. Meteorol. Atmos. Phys. 2019, 131, 1753-1761. [CrossRef]

25. Philip, S.; Kew, S.F.; Jan van Oldenborgh, G.; Otto, F.; O’Keefe, S.; Haustein, K.; King, A.; Zegeye, A.; Eshetu, Z.; Hailemariam, K. Attribution analysis of the Ethiopian drought of 2015. J. Clim. 2018, 31, 2465-2486. [CrossRef]

26. Ayalew, D.; Tesfaye, K.; Mamo, G.; Yitaferu, B.; Bayu, W. Variability of rainfall and its current trend in Amhara region, Ethiopia. Afr. J. Agric. Res. 2012, 7, 1475-1486.

27. Benti, F.; Abara, M. Trend Analyses of Temperature and Rainfall and Their Response to Global $\mathrm{CO}_{2}$ Emission in Masha, Southern Ethiopia. Caraka Tani J. Sustain. Agric. 2019, 34, 67-75. [CrossRef]

28. Asfaw, A.; Simane, B.; Hassen, A.; Bantider, A. Variability and time series trend analysis of rainfall and temperature in northcentral Ethiopia: A case study in Woleka sub-basin. Weather Clim. Extrem. 2018, 19, 29-41. [CrossRef]

29. Shawul, A.A.; Chakma, S. Trend of extreme precipitation indices and analysis of long-term climate variability in the Upper Awash basin, Ethiopia. Theor. Appl. Climatol. 2020, 140, 635-652. [CrossRef]

30. Cheung, W.H.; Senay, G.B.; Singh, A. Trends and spatial distribution of annual and seasonal rainfall in Ethiopia. Int. J. Climatol. J. R. Meteorol. Soc. 2008, 28, 1723-1734. [CrossRef]

31. Araro, K.; Legesse, S.A.; Meshesha, D.T. Climate Change and Variability Impacts on Rural Livelihoods and Adaptation Strategies in Southern Ethiopia. Earth Syst. Environ. 2020, 4, 15-26. [CrossRef]

32. Wagesho, N.; Goel, N.; Jain, M. Temporal and spatial variability of annual and seasonal rainfall over Ethiopia. Hydrol. Sci. J. 2013, 58, 354-373. [CrossRef]

33. Korecha, D.; Barnston, A.G. Predictability of June-September rainfall in Ethiopia. Mon. Weather Rev. 2007, 135, 628-650. [CrossRef]

34. Gleixner, S.; Keenlyside, N.; Viste, E.; Korecha, D. The El Niño effect on Ethiopian summer rainfall. Clim. Dyn. 2017, 49, 1865-1883. [CrossRef]

35. Singh, R.; Worku, M.; Bogale, S.; Cullis, A.; Adem, A.; Irwin, B.; Lim, S.; Bosi, L.; Venton, C.C. Reality of Resilience: Perspectives of the 2015-16 Drought in Ethiopia; BRACED Resilience Intel, 2016; pp. 1-28. Available online: https://www.preventionweb.net/ files/51332_resilienceintelethiopiapaperweb.pdf (accessed on 15 April 2021).

36. Hailemariam, A.; Haddis, F. Factors affecting unmet need for family planning in southern nations, nationalities and peoples region, Ethiopia. Ethiop. J. Health Sci. 2011, 21, 77-90. [CrossRef]

37. Ethiopia, C. Summary and Statistical Report of the 2007 Population and Housing Census; Federal Democratic Republic of Ethiopia Population Census Commission: Addis Ababa, Ethiopia, 2008.

38. Esayas, B.; Simane, B.; Teferi, E.; Ongoma, V.; Tefera, N. Climate variability and farmers' perception in Southern Ethiopia. Adv. Meteorol. 2019, 2019, 7341465. [CrossRef]

39. Funk, C.; Peterson, P.; Landsfeld, M.; Pedreros, D.; Verdin, J.; Shukla, S.; Husak, G.; Rowland, J.; Harrison, L.; Hoell, A. The climate hazards infrared precipitation with stations-A new environmental record for monitoring extremes. Sci. Data 2015, 2, 150066. [CrossRef]

40. Toté, C.; Patricio, D.; Boogaard, H.; Van der Wijngaart, R.; Tarnavsky, E.; Funk, C. Evaluation of satellite rainfall estimates for drought and flood monitoring in Mozambique. Remote Sens. 2015, 7, 1758-1776. [CrossRef]

41. Lemma, E.; Upadhyaya, S.; Ramsankaran, R. Investigating the performance of satellite and reanalysis rainfall products at monthly timescales across different rainfall regimes of Ethiopia. Int. J. Remote Sens. 2019, 40, 4019-4042. [CrossRef]

42. Dinku, T.; Block, P.; Sharoff, J.; Hailemariam, K.; Osgood, D.; del Corral, J.; Cousin, R.; Thomson, M.C. Bridging critical gaps in climate services and applications in Africa. Earth Perspect. 2014, 1, 15. [CrossRef]

43. Agung Setianto, A.S.; Tamia Triandini, T.T. Comparison of kriging and inverse distance weighted (IDW) interpolation methods in lineament extraction and analysis. J. Southeast Asian Appl. Geol. 2013, 5, 21-29. 
44. Birara, H.; Pandey, R.; Mishra, S. Trend and variability analysis of rainfall and temperature in the Tana basin region, Ethiopia. J. Water Clim. Chang. 2018, 9, 555-569. [CrossRef]

45. Dinku, T.; Hailemariam, K.; Maidment, R.; Tarnavsky, E.; Connor, S. Combined use of satellite estimates and rain gauge observations to generate high-quality historical rainfall time series over Ethiopia. Int. J. Climatol. 2014, 34, 2489-2504. [CrossRef]

46. Gissila, T.; Black, E.; Grimes, D.; Slingo, J. Seasonal forecasting of the Ethiopian summer rains. Int. J. Climatol. J. R. Meteorol. Soc. 2004, 24, 1345-1358. [CrossRef]

47. Svoboda, M.; Hayes, M.; Wood, D. Standardized Precipitation Index User Guide; World Meteorological Organization: Geneva, Switzerland, 2012.

48. Hänsel, S.; Schucknecht, A.; Matschullat, J. The Modified Rainfall Anomaly Index (mRAI)—Is this an alternative to the Standardised Precipitation Index (SPI) in evaluating future extreme precipitation characteristics? Theor. Appl. Climatol. 2016, 123, 827-844. [CrossRef]

49. Agnew, C.; Chappell, A. Drought in the Sahel. GeoJournal 1999, 48, 299-311. [CrossRef]

50. Babatolu, J.S.; Akinnubi, R.T. Surface temperature anomalies in the river Niger basin development authority areas, Nigeria. Atmos. Clim. Sci. 2013, 3, 37125. [CrossRef]

51. Koudahe, K.; Kayode, A.J.; Samson, A.O.; Adebola, A.A.; Djaman, K. Trend analysis in standardized precipitation index and standardized anomaly index in the context of climate change in Southern Togo. Atmos. Clim. Sci. 2017, 7, 401-423. [CrossRef]

52. McKee, T.B.; Doesken, N.J.; Kleist, J. The relationship of drought frequency and duration to time scales. In Proceedings of the 8th Conference on Applied Climatology, Anaheim, CA, USA, 17-22 January 1993; pp. 179-183.

53. Viste, E.; Korecha, D.; Sorteberg, A. Recent drought and precipitation tendencies in Ethiopia. Theor. Appl. Climatol. 2013, 112, 535-551. [CrossRef]

54. Hare, W. Assessment of Knowledge on Impacts of Climate Change-Contribution to the specification of art. 2 of the UNFCCC: Impacts on ecosystems, food production, water and socio-economic systems. Arctic 2003, 100, 6.

55. De Luis, M.; Raventós, J.; González-Hidalgo, J.; Sánchez, J.; Cortina, J. Spatial analysis of rainfall trends in the region of Valencia (East Spain). Int. J. Climatol. J. R. Meteorol. Soc. 2000, 20, 1451-1469. [CrossRef]

56. Gocic, M.; Trajkovic, S. Analysis of changes in meteorological variables using Mann-Kendall and Sen's slope estimator statistical tests in Serbia. Glob. Planet. Chang. 2013, 100, 172-182. [CrossRef]

57. Oliver, J.E. Monthly precipitation distribution: A comparative index. Prof. Geogr. 1980, 32, 300-309. [CrossRef]

58. Karabulut, M. Drought analysis in Antakya-Kahramanmaraş Graben, Turkey. J. Arid Land 2015, 7, 741-754. [CrossRef]

59. Mann, H.B. Nonparametric tests against trend. Econom. J. Econom. Soc. 1945, 13, 245-259. [CrossRef]

60. Kendall, M.G. Rank Correlation Methods; Charles Griffin \& Co. Ltd.: London, UK, 1975.

61. Birsan, M.-V.; Molnar, P.; Burlando, P.; Pfaundler, M. Streamflow trends in Switzerland. J. Hydrol. 2005, 314, 312-329. [CrossRef]

62. Sen, P.K. Estimates of the regression coefficient based on Kendall's tau. J. Am. Stat. Assoc. 1968, 63, 1379-1389. [CrossRef]

63. Mengistu, D.; Bewket, W.; Lal, R. Recent spatiotemporal temperature and rainfall variability and trends over the Upper Blue Nile River Basin, Ethiopia. Int. J. Climatol. 2014, 34, 2278-2292. [CrossRef]

64. Matthews, H.D.; Zickfeld, K.; Knutti, R.; Allen, M.R. Focus on cumulative emissions, global carbon budgets and the implications for climate mitigation targets. Environ. Res. Lett. 2018, 13, 010201. [CrossRef]

65. Seleshi, Y.; Zanke, U. Recent changes in rainfall and rainy days in Ethiopia. Int. J. Climatol. J. R. Meteorol. Soc. 2004, 24, 973-983. [CrossRef]

66. Gashaw, T.; Mebrat, W.; Hagos, D.; Nigussie, A. Climate change adaptation and mitigation measures in Ethiopia. J. Biol. Agric. Healthc. 2014, 4, 48-152.

67. Jury, M.R. Ethiopian decadal climate variability. Theor. Appl. Climatol. 2010, 101, 29-40. [CrossRef]

68. Bahaga, T.K.; Fink, A.H.; Knippertz, P. Revisiting interannual to decadal teleconnections influencing seasonal rainfall in the Greater Horn of Africa during the 20th century. Int. J. Climatol. 2019, 39, 2765-2785. [CrossRef]

69. Gebregiorgis, D.; Rayner, D.; Linderholm, H.W. Does the IOD Independently Influence Seasonal Monsoon Patterns in Northern Ethiopia? Atmosphere 2019, 10, 432. [CrossRef]

70. Alemu, M.M.; Bawoke, G.T. Analysis of spatial variability and temporal trends of rainfall in Amhara region, Ethiopia. J. Water Clim. Chang. 2020, 11, 1505-1520. [CrossRef]

71. Bayecha, D.K. Economic Impacts of Climate Change on Teff Production in Lume and Gimbichu Districts of Central Ethiopia. Master's Thesis, Sokoine University of Agriculture, Morogoro, Tanzania, 2013.

72. Kasie, T.A.; Demissie, B.S.; Bahry, M.J.; Gessesse, G.M.; Wale, L.E. The impact of the 2015 El Niño-induced drought on household consumption: Evidence from rural Ethiopia. Clim. Dev. 2020, 12, 854-863. [CrossRef]

73. Amsalu, A.; Adem, A. Assessment of Climate Change-Induced Hazards, Impacts and Responses in the Southern Lowlands of Ethiopia; Forum for Social Studies (FSS): Addis Ababa, Ethiopia, 2009.

74. Gidey, E.; Dikinya, O.; Sebego, R.; Segosebe, E.; Zenebe, A. Modeling the spatio-temporal meteorological drought characteristics using the standardized precipitation index (SPI) in raya and its environs, northern Ethiopia. Earth Syst. Environ. 2018, 2, $281-292$. [CrossRef]

75. Mekonen, A.A.; Berlie, A.B.; Ferede, M.B. Spatial and temporal drought incidence analysis in the northeastern highlands of Ethiopia. Geoenviron. Disasters 2020, 7, 10. [CrossRef] 